\title{
THE APPLICATION OF QSPM MATRIX WITH SWOT TO DETERMINE THE CONVERSION OF THE CONVENTIONAL ADMINISTRATION SYSTEM TO PAPERLESS
}

\author{
Santi Eka Putri \\ Master Management Program Student \\ Mercu Buana University, Jakarta, Indonesia
}

\begin{abstract}
This study aims to compile an analysis to decide to maintain the conventional administrative system that has been used or replace it with a paperless administrative system using a Strategic Management analysis tool, namely SWOT and QSPM Matrix. QSPM Matrix uses three stages of strategy formulation: the input stage, the matching stage, and the decision-making stage. In the first stage, the IFE Matrix (Internal Factor Evaluation) and the EFE Matrix (External Factor Evaluation) are used. In the second stage, SWOT (Strengths, Weaknesses, Opportunities, and Threats) Matrix and IE (InternalExternal) Matrix are used. In stage three, QSPM (Quantitative Strategic Planning Matrix) is used. The results showed that the decision to convert the Administrative Information System from conventional system to paperless are favourable and the strategies in utilizing information technology in every administrative field in the office will produce better job performance than manually.
\end{abstract}

Keyword : Paperless, QSPM, SWOT.

\section{INTRODUCTION}

The development of information technology is more rapid than ever. Communication between divisions has been carried out with the help of technology, using smartphone and internet applications. Current job demands are increasingly high and complex, competition and the presence of information technology in conducting business, force companies must be able to adjust to changes and take advantage of the state of development and existing technology.

The development of information computer technology has influenced all aspects of life both personally and business institutions such as offices. The patterns of work behavior that still applies traditional offices with modern office equipment only results in work effectiveness, but does not produce work efficiency. This change in work behavior indirectly plays a role in helping to improve the environment, because every

\author{
Setyo Riyanto \\ Associate Professor \\ Mercu Buana University, Jakarta, Indonesia
}

sheet of paper used is the result of logging as the main ingredient. The application of modern work behavior patterns will have a significant impact if carried out in each office sectors.

The company discussed in this journal is an advertising company that has several divisions that routinely communicate digitally. Communication with consumers is done intensively, where corrections and input from clients must be quickly carried out and communicated back to the client. Meetings are held in various locations, not necessarily in the office, also by utilizing teleconferences. In the course of business activities, the company has made several policy changes in carrying out the company's daily activities. Communication with clients is one of the important factors that companies consider to develop information technology in the office. But in line with that, it turns out that more and more needs are found.

For example, in meeting the communication needs of clients, initially were held using emails, and sharing files using Google Drive or Dropbox. But it turns out then the Cloud media is needed to be able to meet the capacity of files and data shared with clients. Transaction data is very large, email only covers a maximum of $25 \mathrm{MB}$, and to upload to a free drive, it takes a large bandwidth and a long time. Also, in daily activities, the administration system must be managed efficiency, that the use of word processor program that is commonly used are not enough. By using better and specific programs, such as accounting programs that can immediately record the evidence brought by operational employees, or tax calculator program will bring better performance in managing the administrative function. This began to encourage corporate leaders to consider turning the company into a paperless office that can respond to company needs.

In this study, the main focus of research is to assist decision making in connection with the use of information technology, the Internet of Things, and the concept of Paperless Office to supervise and control the performance of production divisions, such as Visual Communication Design, Production House, and Marketing and meet administrative compliance with service support (Administrative, Accounting, 
Finance, and Tax) so that the workflow from when the job is received up to billing the clients can be fulfilled by all requirements needed. Also, the use of information technology in terms of communication between divisions and with the client also upgraded because based on experience, communication problem are problems that can be fatal.

\section{THEORETICAL REVIEW}

\section{Strategy}

Rangkuti (2008) stated that "Strategy is a tool to achieve company goals concerning long-term goals, follow-up programs, and priorities for resource allocation. The point of the strategy is the choice to carry out different activities or to carry out activities differently from its competitors".

\section{Strategic Management}

Strategic management, according to Wheelen, Hunger, Hoffman \& Bamford (2018), strategic management is "a set of managerial decisions and actions that help determine the long-term performance of an organization. It includes environmental scanning (both external and internal), strategy formulation (strategic or long-range planning), strategy implementation, and evaluation and control". Meanwhile, according to David \& David, (2017) strategic management is "the art and science of formulating, implementing, and evaluating cross-functional decisions that enable an organization to achieve its objectives".

\section{E-Office}

The term was coined to include the increasing use of computer-based information technology for office work, especially in the 1980s. Initially a popular marketing word in that era, it is no longer widely used because all modern offices are offices using electronic devices.

\section{Paperless Office}

An office called "paperless" is if the office carries out the practice where information is created, stored, processed, and shared in electronic form. A paperless office eliminates all forms of paper by converting it into digital documents. This can be done by investing in a scanner and document management software (DMS), the two main components of a paperless office.

An electronic scanner captures and converts paper documents into electronic form. Then the documents can then be managed, stored, and retrieved using document management software. In real-life situations, the goal of a 'paperless office solution' can be difficult to achieve. Nevertheless, document management software systems make it easy for organizations to move to paperless systems.

The term "The Paperless Office" was first used in commerce by Micronet, Inc., an automated office equipment company, in 1978. And then defined as "a telecommunications-based information system that collects, processes, stores and distributes messages, documents, and other electronic communications between individuals, workgroups, and organizations".

Office automation consists of all formal and informal electronic systems, especially those relating to the communication of information to and from people inside and outside the company. People in an office can use office automation to communicate with people in other offices in a company, or with others in offices in other companies.

\section{E-Administration}

This refers to one of several mechanisms that change administrative protocols in conventional offices that still use paper into an electronic process, to create a paperless office, to increase productivity and performance. E-Administration can include intra-office and inter-office communication. The ultimate goal is total transparency and accountability which leads to better corporate governance.

\section{Smart Office}

The concept of smart office has several meanings, including "Smart Office is a concept that understands individual needs combined with innovative thinking and the latest technology to support so that all employees can unleash all the potential that exists for the good of the company. An office cannot be said to be smart before its technology and services can support every individual who works in it" (Surya, 2016)

There is also research that proposes that smart offices must be supported by appropriate hardware as part of business activity control, not just by utilizing popular applications, such as Smart Office Monitoring Systems Using IoT (S., Arun, Likith, Reddy, K., Dharshan, \& N., Srinivasa., (2019)), Complete Office Handbook: The Definitive Reference for Today's Electronic Office (Jaderstrom, Kruk, Miller \& Fenner (2002)). The company chose to make changes to the teleconference hardware in addition to the fingerprint attendance system.

\section{Cloud Computing}

Cloud Computing is a collection of several resources integrated into one and used through the web. Cloud Computing is based on grid computing technology that makes the size of a computer system very large by combining several computer resources into one resource. So that cloud computing is often referred to as grid computing combined with virtualization.

Cloud Computing has been developing since the sixties along with the development of the internet and the web. The internet is experiencing faster development so that it is driving the development of Cloud Computing technology.

\section{Information Systems}

Understanding the information system is a combination of organized and interrelated components that are 


\section{International Journal of Engineering Applied Sciences and Technology, 2020 \\ Vol. 5, Issue 2, ISSN No. 2455-2143, Pages 87-97 \\ Published Online June 2020 in IJEAST (http://www.ijeast.com)}

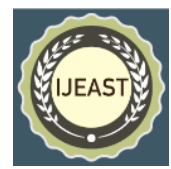

used as a means for individuals or organizations to collect, process, store and distribute information and disseminate that information into an organization or company whose results will be made a supporting tool in decision making in a company, organization or office.

O'Brien and Marakas, (2011) assert that information systems are an organized combination of human resources, hardware, software, data communication network policies and procedures for storing, maintaining, changing, and disseminating information in an organization.

\section{Company Information System (CIS)}

CIS is a system of planning and internal control of a company that includes the use of people, documents, technology, and procedures by management accounting to solve business problems such as administrations, finance, or business strategy. Inside the Company Information System, there are Management Information Systems, Financial Information Systems, and Accounting Information Systems. Each SI has scope and boundaries as well as relationships with one another, and only by making all SI work well together can the Company Information System work properly.

Management Information Systems (MIS) are used to analyses other information systems that are applied to the organization's operational activities. Lipursari (2013) states that "Management Information Systems (MIS) are information networks needed by leaders in carrying out their duties (for the benefit of the organization), especially in making decisions in achieving organizational goals".

Accounting Information System (AIS), is a system that collects, stores, and processes financial and accounting data used by decision-makers. Accounting information is a system that is generally computer-based and a method for tracking accounting activities concerning information technology resources. According to Nuryanti \& Suprantiningrum (2016), SIA has many important roles in the company, such as improving quality and reducing costs in producing goods and services, improving decision making, and creating competitive advantage.

Human Resources Information System (HRIS), is a system whose job is to collect and maintain data describing human resources, convert the data into information, and report that information to the user, where the data that has been obtained is the data needed by a company to improve HR decisions. HRIS is an information system to support the activities of managers in the human resource function.. Riyanto, Sutrisno, \& Ali, (2017) states that all organizations will certainly make every effort to fix the shape and improve the quality of employee performance with the management of human resources is good.

Tax Information System (TIS) or Tax Management Information System (TMIS), usually as a part of the company's Accounting Information System wherein this information system regulates corporate tax liability in connection with business activities, including those related to human resources. Most companies put this Tax Information System still not stand alone and are still under the SIM or SIA, because taxation is indeed very closely related to business activities and accounting records. Darono (2009), stated the need for tax management as the correct management of tax rights and obligations so that the amount of tax paid can be reduced as low as possible to obtain the expected profit and liquidity.

\section{QSPM Matrix (Quantitative Strategic Planning Matrix) \\ QSPM (Quantitative Strategic Planning Matrix) is an} analytic technique in the literature designed to determine the relative attractiveness of viable alternative actions. This matrix uses input from IFE and EFE analysis and also matches the SWOT / TOWS matrix and IE matrix. QSPM is a highlevel strategic management approach to evaluating strategies that can be undertaken. QSPM provides an analytical method for comparing at least two feasible alternative actions. The QSPM method is included in the so-called stage 3 of the analytical framework for strategy formulation.

When company executives think about what to do, and where to go, they usually have a list of prioritized strategies. If there is a strategy that is preferred over the others, they include it in the analysed list. This process is very intuitive and subjective. The QSPM method uses numbers into the calculation of this analysis and makes it more technical.

The Quantitative Strategic Planning Matrix or the QSPM approach seeks to objectively choose the best strategy using inputs from other management techniques and some easy calculations. In other words, the QSPM method uses the input of phase 1 analysis, matches it with the results of the phase 2 analysis, and then decides objectively between alternative strategies. QSPM compares the two alternatives that companies can choose based on the strategy in stage 1 (IFE, EFE) and stage 2 (SWOT, IE), company executives can make the best decision for the company.

\section{IFE (Internal Factor Evaluation)}

The Internal Factor Evaluation Matrix (IFE) is a strategic management tool for auditing or evaluating key strengths and weaknesses in the functional area of business. IFE is an analysis of internal factors that include strengths and weaknesses that can affect company performance. A summary of the IFE analysis is illustrated in the IFE Matrix.

The IFE matrix also provides a basis for identifying and evaluating relationships between these areas. The Internal Factor Evaluation Matrix or short IFE matrix is used in the formulation of the strategy. The IFE matrix together with the EFE matrix is a strategy formulation tool that can be used to evaluate a company's performance in terms of identifying the company's internal strengths and weaknesses. The IFE matrix method is conceptually related to the Balanced Scorecard method in several aspects. 


\section{International Journal of Engineering Applied Sciences and Technology, 2020 \\ Vol. 5, Issue 2, ISSN No. 2455-2143, Pages 87-97 \\ Published Online June 2020 in IJEAST (http://www.ijeast.com)}

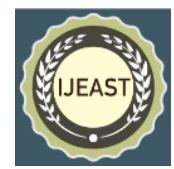

Regardless of how many factors are included in the IFE Matrix, the weighted total score can range from as low as 1.0 to as high as 4.0 (assuming the Company uses a rating scale of 1 to 4 ). The average score that the Company can get is 2.5 . Why does it average 2.5 and not 2.0? If the company has 4 factors, each has a weight of 0.25 . These factors will have the following rankings: $1,4,1,4$. This will produce an individual weighted score of $0.25,1,0.25$, and 1 for factors 1 to 4 . If the Company adds them,

Companies will get a total IFE matrix weighting score of 2.5 which is also an average in this case. The total weighted weight score well below 2.5 indicates that business is weak internally. Significant scores above 2.5 indicate a strong internal position.

\section{EFE (External Factor Evaluation)}

The External Factor Evaluation (EFE) matrix method is a strategic management tool that is often used to assess current business conditions. The EFE matrix is a good tool for visualizing and prioritizing opportunities and threats facing the business.

Zulkarnaen, \& O.H, Sutopo. (2013) stated that "This is a tool used to measure the weight of each determinant that has been taken from the company's external circumstances". EFE is an analysis of external factors that include opportunities and threats that can affect company performance. A summary of the EFE analysis is included in the IFE table.

The EFE matrix is very similar to the IFE matrix, in terms of developing the matrix. The main difference between the EFE matrix and the IFE matrix is the type of factors included in the model. While the IFE matrix deals with internal factors, the EFE matrix only deals with external factors.

External factors assessed in the EFE matrix are factors that are subject to social, economic, political, legal, and other external forces. Factors that can be taken into account in the EFE can be grouped into the following groups:

1. Social, cultural, demographic, and environmental variables:

2. Economic variables

3. Political variables, government, business trends, and law

\section{SWOT analysis}

One approach that can be used as an instrument in choosing a basic strategy is through SWOT analysis. SWOT analysis can be used to evaluate opportunities and challenges in the business environment and the company's internal environment, Rangkuti (2008) explains that the SWOT analysis is the systematic identification of various factors to formulate a company's strategy.

This analysis is based on a logic that can maximize strengths and opportunities, but at the same time minimize weaknesses and threats (Quincy, et.al. (2012)). The decision- making process in this way is always associated with the development of business mission, goals, strategies, and policies. So, in principle, the SWOT analysis compares external factors (Opportunities and Threats) and internal factors (Strengths and Weaknesses) to determine the formulation of strategic planning in the effort to formulate long-term strategies.

\section{I-E Matrix (Internal-External Matrix)}

Internal-External Matrix (IE) is another strategic management tool used to analyze working conditions and business strategy positions. The Internal External Matrix or IE matrix is based on an analysis of internal and external business factors that are combined into one suggestive model. IE Matrix is a continuation of the EFE and IFE matrix models.

Tyas, S.K. \& Chriswahyudi (2017) states "IE matrix is based on two main dimensions, the weighted average total IFE on the $\mathrm{X}$-axis and the total weighted average EFE on the Y-axis". IE Matrix is included in the strategic portfolio management tool group. In the same way as the BCG matrix, the IE matrix positions an organization into a nine-cell matrix.

\section{RESEARCH METHODS}

\section{Types of research}

This research uses descriptive research method. Descriptive research is a research method that seeks to describe an object following the situation or what it is.

\section{Data collection technique}

In this study the authors collected data with the following techniques:

a. Field Work Research

Direct data collection which is the object of research to look closely at the company, using the method of observation or observation through the statement of one of the employees in the company who directly see and experience the daily activities of the company.

b. Library Research

Collecting secondary data or data obtained from data that has been recorded, both in the form of reports and the results of previous research.

\section{Analysis Tool}

Data Compilation of decision making using the SWOT method and Quantitative Strategic Planning Matrix (QSPM) using three stages of the implementation of data analysis. In more detailed stages of data analysis as follows (Quincy, 2012), (Tyas, 2017):

a. The Input Stage

The matrixes used in this stage are Internal Factor Evaluation (IFE) matrix and External Factor Evaluation (EFE) matrix. The stages in the preparation of the IFE and EFE matrix are: 


\section{International Journal of Engineering Applied Sciences and Technology, 2020 \\ Vol. 5, Issue 2, ISSN No. 2455-2143, Pages 87-97 \\ Published Online June 2020 in IJEAST (http://www.ijeast.com)}

i. Identification of Internal and External Factors of the Company The identification of internal factors is to register all the strengths and weaknesses of the company. The presentation of data with positive factors (Strengths) is written before negative factors (Weaknesses). Similarly, the identification of external factors of the company.

ii. Giving weight to each factor. Weight determination in the company's internal and external analysis is done by asking questions to respondents using the paired comparison method (pairwise comparison).

iii. Rating describes how effective a company's current strategy is in responding to existing strategic factors. The rating is based on the following information:

(1) Value 4, If the company has a very good ability to achieve the opportunity factor, the threat factor has a very weak influence on the company.

(2) Value 3, if the company has a good ability to achieve the opportunity factor and the threat factor has a weak influence on the company.

(3) Value 2, if you have good enough ability to achieve the opportunity factor and the threat factor has a strong influence on the company.

(4) Value 1, if the company has a bad ability to achieve the opportunity factor and the threat factor has a strong influence on the company

iv. Weight multiplication and rating Determine the weighted value of each factor obtained from weight multiplication by rating (ranking) each factor. The weighted values of each factor are then summed to obtain the total weighted values.

b. The Matching Stage

i. IE Matrix (Internal External)

This matrix is useful for positioning the company into a matrix consisting of 9 cells. The IE matrix consists of two dimensions, namely the total score of the IFE matrix on the X-Axis and the EFE Matrix on the YAxis. This matrix is grouped into three main strategies, which are:

(1) Grow and Build are in cells I, II, or IV. Suitable strategies are intensive (market penetration, market development, and product development) or integration (backward integration, forward integration, and horizontal integration).

(2) Hold and Maintain include cell III, V, or cell VII. The general strategy used is market penetration, product development, and market development.
(3) Harvest and Devest cover cells VI, VIII, or IX. The strategy used is divestment diversification strategies and liquidation strategies.

ii. SWOT Matrix

The SWOT matrix is a decision-making formulation tool to determine the strategy adopted based on logic to maximize strengths and opportunities, but at the same time can minimize the company's weaknesses and threats.

The steps in developing a SWOT matrix are as follows:

(1) Compile a list of opportunities and external threats of the company and the company as well as the strengths and weaknesses of the company's internal

(2) Develop an SO (Strength-Opportunity) strategy by matching internal strengths and external opportunities.

(3) Develop a WO (Weakness-Opportunity) strategy by matching internal weaknesses and external opportunities.

(4) Develop a strategy of ST (Strength Threat) by matching internal forces and external threats.

(5) Develop a WT (Weakness Threat) strategy by matching internal weaknesses and external threats.

c. The Decision Stage

The matrix used in this decision is QSPM. QSPM analysis is used to evaluate strategies objectively based on the main internal-external success factors identified in the previous stage.

The steps in preparing the QSPM matrix are as follows:

i. Make a list of external opportunities/threats and the company's key internal strengths/weaknesses in the left column in QSPM. This information is obtained from the EFE and IFE matrices.

ii. Give weights for each internal and external factor (the weights given are the same as the weights in the EFE and IFE matrices).

iii. Evaluate the phase 2 matrix (matching) and identify alternative strategies that the organization must consider to implement.

iv. Determine the value of Attractiveness (AS), defined as a number that indicates the relative attractiveness of each strategy in a particular alternative set. Value $1=$ not interesting, Value 2 $=$ rather interesting, Value $3=$ quite interesting, Value $4=$ very interesting, Value $0=$ not relevant.

v. The Total Attractive Score (TAS) is obtained by multiplying the weight by the attractiveness score. The higher the total value of attractiveness, the more attractive alternative strategies.

vi. Calculate the total value of attraction. Add the total attraction value in each QSPM strategy 
column. The total number of attractiveness values reveals which strategy is most attractive in each strategy cell.

\section{IV.RESULTS AND DISCUSSION}

1. Stage I (Input Stage): Evaluation of Internal Factors (IFE) and Evaluation of External Factors (EFE)

Stage I is called the input stage because this stage includes internal and external factors which are the basic information needed to find out which marketing strategies exist in accordance with the company. Phase I uses the Internal Factor Evaluation Matrix (IFE) and the External Factor Evaluation Matrix (EFE).

\section{b. Internal Factor Evaluation = IFE}

Table 1 The IFE Matrix shows the average total score for a power factor of 1.79 . While the average total score for the weakness factor is 1.59. This shows that the key strength factor is greater than the weakness factor, therefore, the company must be able to maximize the strengths available to overcome the weaknesses faced.

Before conducting a SWOT analysis, classification, and analysis of internal factors (strengths and weaknesses of the business) are carried out. The analysis of the factors is as follows (Rangkuti, 2014):

The procedure for analysing internal factors (IFE = Internal Factor Evaluation) is as follows:

b. Weights are given from 1.00 to 0.00 (from very important to not important) depending on the magnitude of the impact of these factors.

c. A rating scale of 5-1 is performed for Strength (a large Strength is given a value of 5 and the smallest is given a value of 1 ).

d. A rating scale of 1-5 is performed for Weakness (the large Weakness is given a value of 1 and the smallest is given a value of 5).

e. Multiplication is performed between weights and ratings so that values are obtained for each factor.

f. The value of each factor is added up so that the total value obtained for the external strategy factor is obtained.

This value shows how the company reacts to internal factors and can be used as a comparison for similar companies.

Internal Factors:

i. Strengths

a. Experience communicating with technology

b. Clients can communicate well through commonly used applications

c. Faster performance, Faster feedback, Employee work becomes more efficient d. The company is very flexible in handling every client request, can respond quickly to these requests

e. The company has a good reputation

f. Companies have low overhead costs, so they can provide the best price offer for customers.

ii. Weaknesses

a. The cost of forming a diverse system, both communication systems with external parties, or internal systems such as accounting, inventory, and management programs.

b. Supporting hardware is needed, such as mobile phones that support applications, accounting programs, and supporting hardware such as scanners.

c. Our staff still have a low ability in certain fields.

d. The company has limited capital

e. Cash flow sometimes is not smooth, due to fluctuating operating costs

f. The office location is located in a less strategic place

\begin{tabular}{|c|c|c|c|}
\hline Figure 1, IFE Matrix & & & \\
\hline IFE Matrix & & & \\
\hline Internal Factors & & & \\
\hline Strength & \begin{tabular}{|l|} 
Rating scale 5-1 \\
(largest: 5, \\
smallest: 1) \\
\end{tabular} & $\begin{array}{l}\text { Quality from } \\
0.00 \text { to } 1.00\end{array}$ & Score \\
\hline $\begin{array}{l}\text { Employee have experiences communicating using } \\
\text { information technology }\end{array}$ & 4 & 0,10 & 0,40 \\
\hline $\begin{array}{l}\text { Communication with client using commonly used } \\
\text { applications }\end{array}$ & 4 & 0,10 & 0,40 \\
\hline $\begin{array}{l}\text { Faster performance, Faster feedback, Employee } \\
\text { work becomes more efficient }\end{array}$ & 3 & 0,10 & 0,30 \\
\hline $\begin{array}{l}\text { The company is very flexible in handling every } \\
\text { client's request, can respond quickly to these } \\
\text { requests. }\end{array}$ & 3 & 0,08 & 0,24 \\
\hline The company has a good reputation & 3 & 0,07 & 0,21 \\
\hline $\begin{array}{l}\text { Companies have low overhead costs, so they can } \\
\text { provide the best price offer for customers. }\end{array}$ & 3 & 0,08 & 0,24 \\
\hline Total & & 0,53 & 1,79 \\
\hline Weakness & $\begin{array}{l}\text { Rating scale 5-1 } \\
\quad \text { (largest: 5, } \\
\text { smallest: 1) }\end{array}$ & $\begin{array}{l}\text { Quality from } \\
0.00 \text { to } 1.00\end{array}$ & Score \\
\hline $\begin{array}{l}\text { The cost of establishing a diverse system, both } \\
\text { communication systems with external parties, or } \\
\text { with internal such as accounting, inventory and } \\
\text { management programs. }\end{array}$ & 3 & 0,10 & 0,30 \\
\hline $\begin{array}{l}\text { Required supporting hardware, such as mobile } \\
\text { phones that support applications, dedicated } \\
\text { computer for accounting programs, and } \\
\text { supporting hardware such as scanners and QR } \\
\text { reader. }\end{array}$ & 5 & 0,08 & 0,40 \\
\hline Employee still has limited ability in certain fields. & 3 & 0,10 & 0,30 \\
\hline The company has limited capital. & 4 & 0,07 & 0,28 \\
\hline $\begin{array}{l}\text { Cash flow is sometimes not smooth, because } \\
\text { operating costs are fluctuating }\end{array}$ & 3 & 0,07 & 0,21 \\
\hline $\begin{array}{l}\text { The office location is located in a less strategic } \\
\text { place. }\end{array}$ & 2 & 0,05 & 0,10 \\
\hline Total & & 0,47 & 1,59 \\
\hline IFAS Score & & 1,00 & $\mathbf{3 , 3 8}$ \\
\hline
\end{tabular}




\section{International Journal of Engineering Applied Sciences and Technology, 2020 \\ Vol. 5, Issue 2, ISSN No. 2455-2143, Pages 87-97 \\ Published Online June 2020 in IJEAST (http://www.ijeast.com)}

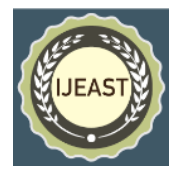

\section{c. Evaluation of External Factors $=$ EFE}

In table 2 of the EFE Matrix, it can be seen that the average total score of the key opportunity factors is 1.96 , while the mean total score of the key threat factors is 0.87 . This shows that the key factors of opportunity are greater than the key factors of threats, so companies must maximize the opportunities available to deal with threats.

Then the classification and analysis of factors of the external strategy $(\mathrm{EFE}=$ External Factor Evaluation $)$ are included.

a. Compiled factors that become opportunities and threats.

b. Weighting is given from 1.00 to 0.00 (from very important to not important) depending on the magnitude of the impact of these factors.

c. 5-1 scale rating is given for Opportunity (Large Opportunity is given a value of 5 and the smallest is given a value of 1 ).

d. A rating scale of 1-5 is performed for Threat (a large Threat is given a value of 1 and the smallest is given a value of 5).

e. Multiplication is performed between weights and ratings so that values are obtained for each factor.

f. The value of each factor is added up so that the total value obtained for the external strategy factor is obtained.

This value shows how a company reacts to its external factors and can be used as a comparison for similar companies.

External Factors:

i. Opportunities

a. Many free application choices, with paid options

b. Decision making is faster

c. Opportunities for business development

d. Able to immediately present the work to the client

e. The advertising industry will still be able to survive in a variety of conditions

f. The government strongly supports businesses that use company services

ii. Threats

a. Differences in applications with clients can be difficult

b. Employee equipment that is not necessarily appropriate

c. Increased workload

d. Changes in competitors' strategies can threaten our position in this field

e. The company is very attentive to customer requests and needs

f. Intense competition in the same sector

Based on these internal and external factors, the IFE (Internal Factor Evaluation) and EFE (External Factor Evaluation) matrix can be seen in Tables 1 and 2. Based on the results of the IFE matrix (Table 1), values are 3.38 and the EFE matrix (Table 2) obtained a value of 2.83 . While the SWOT matrix is presented in Table 3.

\begin{tabular}{|c|c|c|c|}
\hline Strength & & & \\
\hline $\begin{array}{l}\text { Employee have experiences } \\
\text { communicating using } \\
\text { information technology }\end{array}$ & \begin{tabular}{|} 
The cost of establishing a \\
diverse system, both \\
communication systems with \\
external parties, or with internal \\
such as accounting, inventory \\
and management programs.
\end{tabular} & $\begin{array}{l}\text { Many free application } \\
\text { available in the market, with } \\
\text { paid options available. }\end{array}$ & $\begin{array}{l}\text { Different applications used by } \\
\text { clients can become } \\
\text { communication barrier }\end{array}$ \\
\hline $\begin{array}{l}\text { Communication with client } \\
\text { using commonly used } \\
\text { applications }\end{array}$ & \begin{tabular}{|c|} 
Required supporting hardware, \\
such as mobile phones that \\
support applications, dedicated \\
computer for accounting \\
programs, and supporting \\
hardware such as scanners and \\
QR reader. \\
\end{tabular} & $\begin{array}{l}\text { Change to make faster } \\
\text { decision making }\end{array}$ & $\begin{array}{l}\text { Employee devices that are not } \\
\text { necessarily compatible }\end{array}$ \\
\hline $\begin{array}{l}\text { Faster performance, Faster } \\
\text { feedback, Employee work } \\
\text { becomes more efficient }\end{array}$ & $\begin{array}{l}\text { Employee still has limited ability } \\
\text { in certain fields. }\end{array}$ & $\begin{array}{l}\text { Opportunities for business } \\
\text { development }\end{array}$ & Increased workload \\
\hline $\begin{array}{l}\text { The company is very flexible in } \\
\text { handling every client's request, } \\
\text { can respond quickly to these } \\
\text { requests. }\end{array}$ & The company has limited capital. & $\begin{array}{l}\text { Able to directly present } \\
\text { results to client }\end{array}$ & $\begin{array}{l}\text { Changes in competitor's } \\
\text { strategy can threaten company } \\
\text { position }\end{array}$ \\
\hline $\begin{array}{l}\text { The company has a good } \\
\text { reputation }\end{array}$ & $\begin{array}{c}\text { Cash flow is sometimes not } \\
\text { smooth, because operating costs } \\
\text { are fluctuating }\end{array}$ & $\begin{array}{l}\text { The advertising industry will } \\
\text { be able to survive in a variety } \\
\text { of conditions }\end{array}$ & $\begin{array}{l}\text { The company is very attentive } \\
\text { to customer requests and } \\
\text { needs. }\end{array}$ \\
\hline $\begin{array}{l}\text { Companies have low overhead } \\
\text { costs, so they can provide the } \\
\text { best price offer for customers. }\end{array}$ & $\begin{array}{l}\text { The office location is located in a } \\
\text { less strategic place. }\end{array}$ & $\begin{array}{l}\text { The government policy } \\
\text { supports advertisement } \\
\text { industries }\end{array}$ & $\begin{array}{l}\text { Fierce competition in the same } \\
\text { sector }\end{array}$ \\
\hline
\end{tabular}

2. Stage 2 (Matching Stage): SWOT and InternalExternal (IE) Matrix

This stage is called the Matching Stage. There are two stages in the matching stage that are used, namely:

The first stage: conducting a SWOT analysis, then using IFE and EFE data to form a SWOT Matrix where a strategy will be found based on a combination of Strength with Opportunity, Strength with Threat, and Weakness with Opportunity and Weakness with Threat.

The second step is to process data from the IFE Matrix and EFE to form the IE Matrix.

\section{a. SWOT analysis}

SWOT analysis includes strengths and weaknesses (Weaknesses) as well as external factors namely opportunities (Opportunity) and threats (Treats) contained in advertising companies that are subject. SWOT analysis is used to see the strengths, weaknesses, opportunities, and threats that will be faced by the company. By seeing the strengths owned and developing these strengths, it is certain that the company will be more advanced than existing competitors. Likewise, the weaknesses that are thought to be fixed so that the company can exist. Opportunities that companies must make the best use of can increase performance and threats that will be faced by companies must be faced by developing performance strategies.

According to Rangkuti (2006) that SWOT is an abbreviation of the internal environment of strengths and weaknesses as well as the external environment of Opportunities and Threats faced by the business world. SWOT analysis compares the external factors of Opportunities and Threats with Strengths and Weaknesses. 
Whereas Koter (2002) states that SWOT analysis is an evaluation of the overall strengths, weaknesses, opportunities, and threats called SWOT analysis.

\section{b. SWOT Matrix}

The total value of the IFAS matrix and EFAS matrix is illustrated in the SWOT analysis diagram and the SWOT matrix combination formula. After obtaining the results of the formulation of an alternative combination of SO, ST, WO, and WT strategies from the internal and external environment in the table above. After obtaining the results of the formulation of an alternative combination of SO, ST, WO, and WT strategies from the internal and external environment in the table above.

The alternative formulation of strategy is an alternative used by the company to run the business going forward. The following is a combination of matrix strategies obtained from indicators and combining internal and external factors, the results can be seen in Table 4 .

\section{i. SWOT / TOWS Matrix Analysis for SO Strategy}

After seeing the Strength and Opportunity owned by the company, the strategy that the company will use to improve and maintain the company's performance at this time is with experience so far, using free applications, can be continued as a companion to paid applications. The company must also begin to have all the applications and programs needed. Clearer communication flow in submissions and communication to clients. Then keep opening opportunities by providing services other than those that already exist. With this strategy, it is expected to become a leader by utilizing existing technology ... especially by maximizing employee performance by utilizing existing technology.

\section{ii. SWOT / TOWS Matrix Analysis for WO Strategy}

From the Weakness and Opportunity owned by the company, must be aware of the costs incurred, must be ensured proportional to the risks posed, because in the not too distant future, the use of technology will be increasingly prevalent and competing companies will use technology that the company must use. Maintaining relations with investors so that the next project can work well. And discipline in recording and reporting field activities. In addition, training for employees must continue to be done so that employees are always up to date. To encourage employees, company leaders must provide reward and punishment programs to the company. Rewards encourage employees to work harder optimally. Then strict punishment for employees who are not responsible in the company (Riyanto, Setyo, et al. 2019).

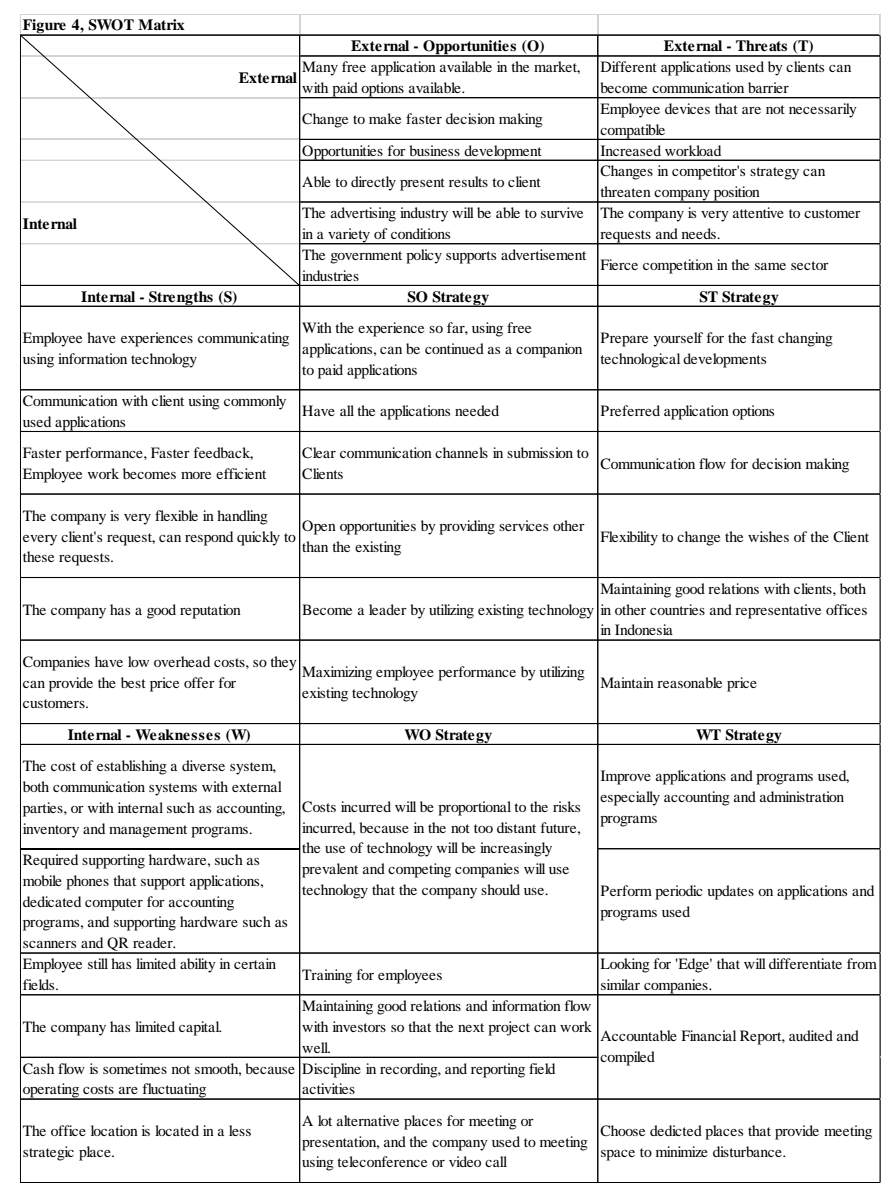

\section{iii. SWOT / TOWS Matrix Analysis for ST Strategy}

Seen from Strength and Threat, companies must be able to use their strength to overcome the threats that come from outside by preparing themselves for rapid technological developments, determining the choice of applications determined in advance so that communication and administration for the better. The flow of communication for better decision making, as well as maintaining flexibility for changing the wishes of the Client does not pose a threat.

\section{iv. SWOT / TOWS Matrix Analysis for the WT Strategy}

In Weakness and Threat, companies must be able to maintain internal weaknesses to avoid threats while maintaining good relations with clients, both those in other countries, as well as representative offices in Indonesia, always doing regular updates on the applications and programs used. Companies must also look for 'Edge' that will distinguish them from similar companies. And regularly improve applications and programs used, especially accounting and administration programs. Create and carry out training regularly. This training must be carefully planned to 


\section{International Journal of Engineering Applied Sciences and Technology, 2020 \\ Vol. 5, Issue 2, ISSN No. 2455-2143, Pages 87-97 \\ Published Online June 2020 in IJEAST (http://www.ijeast.com)}

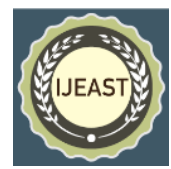

examine the needs of administrators in the future (Riyanto, Setyo, et al. 2017).

\section{b. Internal - External (IE) Matrix}

IE Matrix Analysis (Internal and External Analysis) is conducted to explain overall what is done by the company with internal and external conditions or IFE and EFE. The total weighted value factor IFE is on the horizontal axis, while the total weighted factor EFE is on the vertical axis.

The IE matrix is based on the following two criteria:

i. Scores of the EFE matrix - these scores are plotted on the y-axis

ii. Scores of the IFE matrix - plotted on the $\mathrm{x}$-axis

IE Matrix works by calculating the total weighted score plot of the EFE matrix on the y-axis and drawing horizontal lines in the matrix graph. Then a score is calculated in the IFE

matrix, plots the score on the $\mathrm{x}$-axis, and draws vertical lines on the graph. The point at which the horizontal line of the matrix meets the vertical line is the determinant of the company's strategy. This point shows the strategy that must be followed by the company.

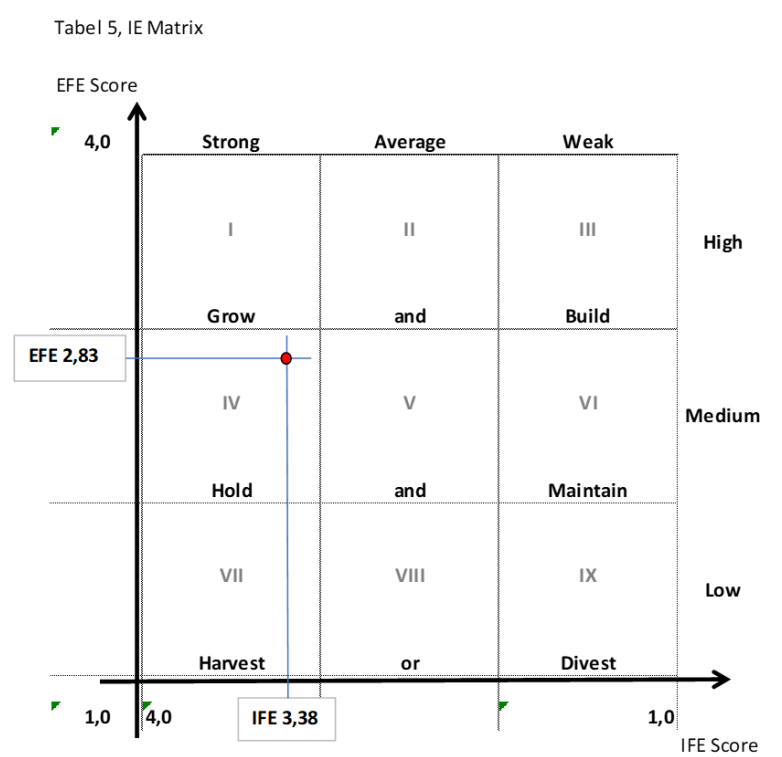

i. On the X-Axis of the IE Matrix, the IFE total weighted score from 1.0 to 1.99 represents a weak internal position. Scores of 2.0 to 2.99 are considered average. A score of 3.0 to 4.0 is strong.

ii. On the Y-Axis, the total weighted EFE score from 1.0 to 1.99 is considered low. Scores of 2.0 to 2.99 are moderate. Scores of 3.0 to 4.0 are high.

The company's horizontal and vertical lines meet in one of the nine cells in the IE matrix. The company must follow a strategy depending on which cell the lines intersect. The IE matrix can be divided into three main areas that have different strategic implications.

i. Cells I, II, and III suggest a grow and build strategy. This means intensive and aggressive tactical strategies. The company's strategy must focus on market penetration, market development, and product development. From an operational perspective, backward integration, forward integration, and horizontal integration must also be considered.

ii. Cells IV, V, and VI suggest a hold and maintain strategy. In this case, the company's tactical strategy must focus on market penetration and product development.

iii. Cells VII, VIII, and IX are operated with the harvest or exit strategy. If the costs to rejuvenate a business are low, then it must be sought to revitalize the business. In other cases, aggressive cost management is a way to play the final game.

This IE Matrix tells us that the company must hold and maintain its position. Companies must pursue a strategy that focuses on increasing market penetration and product development.

\section{Stage 3 (Decision Stage): QSPM Matrix (Quantitative Strategic Planning Matrix)}

This stage is called the Decision Stage. This stage uses input from stage I information to objectively evaluate the results of stage 2 so that the best alternative strategy will be chosen. The tool used at this stage is the Quantitative Strategic Planning Matrix (QSPM). Based on the SWOT / TOWS analysis, there are alternative strategies to support the company's economic growth by utilizing technology. To determine the right alternative strategy as a priority, a QSPM analysis was carried out. QSPM analysis can be seen in Table 5.

As can be seen in the results of the QSPM Matrix analysis, based on the calculation of weights with Attractiveness Scores, the choice to continue the plan to change the information system within the company into paperless is more favourable $(6,67)$ than maintaining conventional information systems $(4,95)$. This result show that the company can start to periodically acquire tools needed to convert the administration system into paperless. 
Figure 6, QSPM (Quantitative Strategic Planning Matriks)

\begin{tabular}{|c|c|c|c|c|c|c|}
\hline \multirow{3}{*}{ Key Factor } & \multicolumn{3}{|c|}{ Alternative 1} & \multicolumn{3}{|c|}{ Alternative 2} \\
\hline & \multicolumn{3}{|c|}{ Konvensional } & \multicolumn{3}{|c|}{ Paperless } \\
\hline & Weight & AS & TAS & Weight & AS & TAS \\
\hline \multicolumn{7}{|l|}{ Strength } \\
\hline $\begin{array}{l}\text { Employee have experiences communicating } \\
\text { using information technology }\end{array}$ & 0,10 & 3 & 0,30 & 0,10 & 4 & 0,40 \\
\hline $\begin{array}{l}\text { Communication with client using commonly } \\
\text { used applications }\end{array}$ & 0,10 & 3 & 0,30 & 0,10 & 4 & 0,40 \\
\hline $\begin{array}{l}\text { Faster performance, Faster feedback, } \\
\text { Employee work becomes more efficient }\end{array}$ & 0,10 & 3 & 0,30 & 0,10 & 4 & 0,40 \\
\hline $\begin{array}{l}\text { The company is very flexible in handling } \\
\text { every client's request, can respond quickly to } \\
\text { these requests. }\end{array}$ & 0,08 & 1 & 0,08 & 0,08 & 3 & 0,24 \\
\hline The company has a good reputation & 0,07 & 2 & 0,14 & 0,07 & 3 & 0,21 \\
\hline $\begin{array}{l}\text { Companies have low overhead costs, so they } \\
\text { can provide the best price offer for } \\
\text { customers. }\end{array}$ & 0,08 & 3 & 0,24 & 0,08 & 3 & 0,24 \\
\hline Weakness & & & 0,00 & & & 0,00 \\
\hline $\begin{array}{l}\text { The cost of establishing a diverse system, } \\
\text { both communication systems with external } \\
\text { parties, or with internal such as accounting, } \\
\text { inventory and management programs. }\end{array}$ & 0,10 & 3 & 0,30 & 0,10 & 4 & 0,40 \\
\hline $\begin{array}{l}\text { Required supporting hardware, such as } \\
\text { mobile phones that support applications, } \\
\text { dedicated computer for accounting programs, } \\
\text { and supporting hardware such as scanners } \\
\text { and QR reader. }\end{array}$ & 0,08 & 3 & 0,24 & 0,08 & 4 & 0,32 \\
\hline $\begin{array}{l}\text { Employee still has limited ability in certain } \\
\text { fields. }\end{array}$ & 0,10 & 2 & 0,20 & 0,10 & 4 & 0,40 \\
\hline The company has limited capital. & 0,07 & 3 & 0,21 & 0,07 & 4 & 0,28 \\
\hline $\begin{array}{l}\text { Cash flow is sometimes not smooth, because } \\
\text { operating costs are fluctuating }\end{array}$ & 0,07 & 3 & 0,21 & 0,07 & 4 & 0,28 \\
\hline $\begin{array}{l}\text { The office location is located in a less } \\
\text { strategic place. }\end{array}$ & 0,05 & 2 & 0,10 & 0,05 & 2 & 0,10 \\
\hline Total Weight & $100 \%$ & & & $100 \%$ & & \\
\hline \multicolumn{7}{|l|}{ Opportunity } \\
\hline $\begin{array}{l}\text { Many free application available in the market, } \\
\text { with paid options available. }\end{array}$ & 0,10 & 2 & 0,20 & 0,10 & 4 & 0,40 \\
\hline Change to make faster decision making & 0,09 & 3 & 0,27 & 0,09 & 4 & 0,36 \\
\hline Opportunities for business development & 0,09 & 3 & 0,27 & 0,09 & 3 & 0,27 \\
\hline Able to directly present results to client & 0,09 & 2 & 0,18 & 0,09 & 4 & 0,36 \\
\hline $\begin{array}{l}\text { The advertising industry will be able to } \\
\text { survive in a variety of conditions }\end{array}$ & 0,08 & 3 & 0,24 & 0,08 & 3 & 0,24 \\
\hline $\begin{array}{l}\text { The government policy supports } \\
\text { advertisement industries }\end{array}$ & 0,08 & 2 & 0,16 & 0,08 & 2 & 0,16 \\
\hline $\begin{array}{c}\text { Threath } \\
\end{array}$ & & & 0,00 & & & 0,00 \\
\hline $\begin{array}{l}\text { Different applications used by clients can } \\
\text { become communication barrier }\end{array}$ & 0,08 & 2 & 0,16 & 0,08 & 4 & 0,32 \\
\hline $\begin{array}{l}\text { Employee devices that are not necessarily } \\
\text { compatible }\end{array}$ & 0,09 & 2 & 0,18 & 0,09 & 4 & 0,36 \\
\hline Increased workload & 0,07 & 4 & 0,28 & 0,07 & 2 & 0,14 \\
\hline $\begin{array}{l}\text { Changes in competitor's strategy can } \\
\text { threaten company position }\end{array}$ & 0,07 & 1 & 0,07 & 0,07 & 1 & 0,07 \\
\hline $\begin{array}{l}\text { The company is very attentive to customer } \\
\text { requests and needs. }\end{array}$ & 0,08 & 2 & 0,16 & 0,08 & 2 & 0,16 \\
\hline Fierce competition in the same sector & 0,08 & 2 & 0,16 & 0,08 & 2 & 0,16 \\
\hline Total Weight & $100 \%$ & & & $100 \%$ & & \\
\hline Total TAS & & & 4,95 & $<$ & & 6,67 \\
\hline
\end{tabular}

TAS $=$ Total Atractiveness Score, AS = Attractiveness Score

(Attractiveness Score: Score $1=$ not attractive, Score $2=$ relatively attractive, Score $3=$

attractive, Score $4=$ highly attractive, Score $0=$ not relevant)

\section{Conclusion}

\section{CONCLUSION}

As a company engaged in the field of advertising, especially those who receive most of their work in the form of digital advertising, companies need qualified information technology. This need not only lies in the technology used such as computers with Photoshop, Phoenix, or digital manipulation. Precisely what has been keeping company performance is applications and programs that help communication, both free ones like Whatsapp, e-mail, or accounting programs like Zahir and MYOB.

These applications guarantee the flow of performance between the client and the company is maintained, between leaders and subordinates can be well communicated. Also, the administration that guarantees billing can be done properly and correctly. The accounting program will maintain investor confidence with the correct accountability report.

The need for applications and programs will support the performance of companies working with projects that tend to neglect the importance of good administration and support systems. It is expected that the company can meet the technological needs that will make the office a smart office that can answer every challenge and answer it to investors.

As evidenced by the advertising companies discussed in this paper, QSPM can be a useful strategic planning tool even for any company. The strategic business decision analysed here is making changes to the Office Information System from conventional to non-paper systems.

This is shown from each analysis tool used to examine the company's administrative system, the system already has a framework that runs well, but changes or improvements to the system must be made so that it can continue to follow changes and developments, which will continue to occur whether the company ready or not.

The success and even survival of this business can depend on the owner to get this strategic decision applied correctly. So QSPM can help, and benefit all types of organizations - big, small, corporate, and non-profit companies - in strategic planning.

\section{Suggestion}

This paper provides guidelines and procedures as well as simple examples to show how QSPM can be successfully used by businesses facing important strategic decisions. In the absence of tools such as QSPM, sometimes strategic decisions are made primarily based on emotions, politics, premonitions, past experiences, and intuition.

The limitation of QSPM is that this tool depends on the prerequisite information and analysis that is the source of the information. Another limitation is that QSPM requires good judgment in determining attractiveness scores. Also, the total number of attractiveness scores can be so close that the final decision is not clear. However, like all analytical tools, QSPM 
may not dictate decisions but must be developed as input into the final decision of the owner.

In actual business settings that often conflicting with various interest and target, these subjective factors can result in loss of income and revenue by producing strategies that fail to create a competitive advantage. QSPM provides an objective framework that can facilitate organizational strategic planning as well as classroom strategic planning.

Overall, the benefits of developing QSPM far outweigh the limitations, because the analysis represents an objective rather than a subjective basis for deciding among viable alternative strategies. Also, QSPM uses the underlying external and internal judgments, rather than storing this information and not using it in deciding between strategies to pursue.

\section{REFERENCES}

[1] Darono, Agung, (2009), Pengembangan Sistem Informasi Manajemen Pajak Berbasis Financial Information System Model : Suatu Kajian Pendahuluan, Seminar Nasional Aplikasi Teknologi Informasi 2009 (SNATI 2009), (p 39-45).

[2] David, Fred R. \& David, Forest R. (2017). Strategic Management: A Competitive Advantage Approach, Concepts and Cases, 16 ${ }^{\text {th }}$ Edition, Pearson Education.

[3] Jaderstrom, Susan, Kruk, Leonard B., Miller, Joanne, \& Fenner, Susan W., (2002), Complete Office Handbook, $3^{\text {rd }}$ ed, Random House Reference.

[4] Kotler, Philip. (2002). Manajemen pemasaran : Analisis, Perencanaan, Implementasi, ed Milenium (Hendra Teguh \& Ronny Antonius Rusli, Penerjemah.). Jakarta: Prenhallindo.

[5] Lipursari, Anastasia (2013), Peran Sistem Informasi Manajemen (SIM) Dalam Pengambilan Keputusan, Jurnal Stie Semarang, Vol 5, No 1, (p 26-37)

[6] Nuryanti, Dwi, \& Suprantiningrum, Rr. (2016), Analisis Dan Perancangan Sistem Informasi Akuntansi Penjualan, Piutang Dan Penerimaan Kas (Studi Kasus pada UD.Praktis di Magetan), Serat Acitya - Jurnal Ilmiah UNTAG Semarang, vol 5, no. 2, (p 100-116).

[7] O'Brien, J.A., \& Marakas, G. M. (2011) Management Information Systems, McGraw-Hill Irwin.

[8] Quincy, Ronald, Lu, Shuang, \& Huang, ChienChung, (2012), SWOT Analysis Raising Capacity of Your Organization, Huamin Philanthropy Brochure Series, September, (p 1-14)

[9] Rangkuti, Freddy. (2006) (2008).Analisa SWOT Teknik Membedah Kasus Bisnis Reorientasi Konsep Perencanaan Strategis untuk Menghadapi Abad $21, .15^{\text {th }}$ ed, Gramedia Pustaka Utama, Jakarta.

[10]Rangkuti, F., (2014). Anasisis SWOT Cara Perhitungan Bobot, Rating, dan OCAI. $19^{\text {th }}$ ed, Gramedia Pustaka : Jakarta 8.
[11]Riyanto, Setyo, \& Panggabean, Mangandar, (2019), The Impact of Leadership, Organizational Culture and Organizational Climate on Employee Job Satisfaction (Case Study: PT Garuda Indonesia (Persero) Tbk), (ICMEB 2019), DOI:10.2991/aebmr.k.200205.007.

[12] Riyanto, Setyo, Yanti, Ria Rahma, \& Ali Hapzi. (2017). The Effect of Training and Organizational Commitment on Performance of the State University of JakartaStudent Cooperative (KOPMA UNJ) Management. Saudi Journal of Humanities and Social Science. (SJHSS), DOI: 10.21276/sjhss.

[13] Riyanto, Setyo, Sutrisno, Ady, \& Ali, Hapzi, (2017), The Impact of Working Motivation and Working Environment on Employees Performance in Indonesia Stock Exchange, International Review of Management and Marketing (IRMM), Vol. 7, No. 3, (p. 342-348)

[14] S., Arun, Likith, Anjaneya Reddy, K., Dharshan, \& N., Srinivasa, (2019) Smart Office Monitoring System Using Iot, International Research Journal of Engineering and Technology (IRJET) Volume: 06 Issue: 04, Apr 2019, (p. 4560- 4564)

[15] Surya, Adi, (2016), Meningkatkan Produktivitas Pegawai Melalui Penerapan Kantor Cerdas (Smart Office), $\quad 6^{\text {th }} \quad$ May $\quad 2020$ https://setjen.pu.go.id/pusdatin/source/File\%20pdf/ Artikel\%20Khusus/meningkatkan-produktivitaspegawai-melalui-penerapan-kantor-cerdas-smartoffice.pdf

[16] Tyas, Sampik Krisning, \& Chriswahyudi. (2017). Perencanaan Strategi Pemasaran Dengan Pendekatan Matrik IE, SWOT Dan AHP Untuk Mendapatkan Alternatif Strategi Prioritas,. Jurnal Teknik Industri, Institut Sains dan Teknologi, Prosiding SEMNASTEK Fakultas Teknik Universitas Muhammadiyah Jakarta (p. 1-9)

[17] Wheelen, Thomas, Hunger, J., Hoffman, Alan \& Bamford, Charles. (2018). Strategic Management and Business Policy:Globalization, Innovation, and Sustainability, 15th Edition, Pearson Education.

[18]Zulkarnaen, O.H, Sutopo. (2013). Analisis Strategi Pemasaran Pada Usaha Kecil Menengah (UKM) Makanan Ringan (Studi Penelitian UKM Snack Barokah di Solo). Diponegoro Journal Of Management. 